\title{
STRATHCLYDE
}

DISCUSSION PAPERS IN ECONOMICS

PRICE FLEXIBILITY AND FULL EMPLOYMENT: BARKING UP THE WRONG (NEOCLASSICAL) TREE

BY

ROY H GRIEVE

No $16-01$

DEPARTMENT OF ECONOMICS

UNIVERSITY OF STRATHCLYDE

GLASGOW 


\title{
Price flexibility and full employment: barking up the wrong (neoclassical) tree
}

\author{
Roy H Grieve*
}

\begin{abstract}
This paper (a revised version of Strathclyde Paper 2004-07) questions the thesis (again in fashion) that price flexibility ensures full employment. (See most standard macro textbooks.) We make the point that explanation of unemployment in terms of price/wage stickiness typified much preKeynesian analysis, but not Keynes's theory of involuntary unemployment. Under uncertainty - an essential aspect of the Keynes conception - no set of prices consistent with full employment may actually exist: if so, price inflexibility is not the critical obstacle to the attainment of full employment. Finally, with respect to current use of the AD/AS model, we note that once-rejected ideas have returned to the mainstream and that the strong arguments against attribution of necessarily beneficent effects to price and wage flexibility, which ought to be well-known, seem now to be forgotten.
\end{abstract}

Key words: price adjustment - the rate of interest, wages, the price level; classical and Keynesian perspectives; "counting equations and unknowns"; the ADAS model

JEL classifications: B13, B22

*roygrieve@btinternet.com 


\section{Price flexibility and full employment: barking up the wrong (neoclassical) tree}

\section{Introduction}

At the present time, standard macro textbooks are wont to convey the view that the "natural" (default) state of the economy is one of full employment, and that unemployment, when it occurs, be considered a temporary, disequilibrium phenomenon resulting from stickiness of prices and consequent slowness of the market mechanism in performing its equilibrating role. It is taken for granted that any upsetting impact of demand disturbances on output and employment will in time be eliminated as the price mechanism "grinds out" the appropriate set of relative values. With respect to the history of economic analysis, the reader is given to understand that Keynes's contribution to macro theory was to direct attention to disequilibrium conditions in the short run, said to be attributable to wage or price stickiness, thereby in effect complementing the traditional ("classical") theory which was concerned primarily with the long-run equilibrium state of the system, with full employment assured via wage and price adjustment.

Take a couple of instances of such textbook pronouncements. One refers to stickiness of relative prices, and the other to inflexibility of the general price level; both associate the Keynesian tradition with non-adjustment of prices, and both associate the persistence of unemployment with inadequate price adjustment. One refers to the price of labour (the real wage rate), the other to the general level of prices.

The classical supply curve is based on the belief that the labour market works smoothly, always maintaining full employment of the labour force. Movements in the wage are the mechanism through which full employment is maintained. The Keynesian aggregate supply curve is instead based on the assumption that the wage does not change much or at all when there is unemployment, and thus that unemployment can continue for some time.

(Dornbusch and Fischer, 1990, p.235) 
We can now see the key difference between the Keynesian and classical approaches to the determination of national income. The Keynesian assumption . . . is that the price level is stuck ... The classical assumption is that the price level is flexible ... The price level adjusts to ensure that national income is always at the natural rate. The classical assumption best describes the long run . . . The Keynesian assumption best describes the short.

(Mankiw, 1994, p.275)

The fact that such views can be asserted today suggests, on the part of their proponents, a lack of familiarity with the course of development of macroeconomic theory together with a worrying want of awareness of the powerful arguments which cast doubt on the thesis that downward price flexibility guarantees full employment. We believe that a review of how thinking on this important issue has evolved may point to a different (Keynesian rather than classical) conception which, from the perspective of mainstream modern macroeconomics, seems all too frequently overlooked or forgotten. The purpose of this paper is therefore to put before the reader a less comfortable interpretation of the working of the macro system which calls in question the validity of the fashionable presumption that, as far as full employment is concerned, it is all a matter of "getting prices right”.

\section{The old classical orthodoxy}

We begin by going back to the earliest debates as to the cause of unemployment in the (then emerging) industrial economy. At the beginning of the nineteenth century, amongst those with an interest in economic affairs, controversy broke out over the possibility of a general "glut" - of the occurrence of a state of affairs characterised by general overproduction relative to demand for output, accompanied by widespread unemployment.

Advocates of what become the orthodox view (J B Say, James Mill, David Ricardo and J. S. Mill) held that no such general deficiency of planned demand relative to productive capacity could ever occur. These early authorities did not however blame observed unemployment on wage rigidity: their position was rather that a macroeconomic problem of general unemployment on account of insufficient overall demand was simply inconceivable. ${ }^{1}$ (As regards the overall level of demand, all that was admitted was the possibility of a temporary - self-correcting - disruption of normal economic activity on the occasion of a commercial crisis.) Orthodox opinion was absolutely confident that the "heretical" fe a r (associated with T R Malthus, Thomas Chalmers and J C L Simonde de Sismondi) of

\footnotetext{
${ }^{1}$ With, in Ricardo's phrase, "a sudden change in the channels of trade", the difficulties of relocating resources might mean that adjustment took some time, but, it was believed, a surplus of output in one sector would be matched by a shortage elsewhere.
} 
"too much" investment creating such expansion of productive capacity as to outrun the growth of demand, was totally without foundation either in theory or in fact. While it was of course recognised that oversupply of any particular commodity could occur, a general state of overproduction across the economy, on account of want of planned demand, was (transient crisis conditions aside) deemed impossible.

Advocates of this position cited "Say's Law" - the proposition that the very act of supplying goods to the market implies a corresponding volume of demand - arguing that a producer was desirous either of consuming his own product or of exchanging it for the products of others. Essentially, the view was that the desire to purchase could not fail to keep up with the volume of goods produced; even if savings were made out of current income, such saving would automatically be matched by planned investment. Thus, from the orthodox perspective, the understanding was simply that, in the natural course of events, demand would grow along with capacity. Orthodox theorists did not admit the possibility of an autonomously-occurring deficiency of demand and so did not think in terms of price adjustment of one form or another as preventing or correcting such a state of affairs.

\section{The neoclassical version: unemployment - "it's all a matter of getting prices right"}

In the neoclassical era it came to be accepted that imbalances (beyond the circumstances of a commercial crisis) between overall demand for output and production capacity could occur (as in the course of the trade cycle). These were now attributed to the imperfect working of the price mechanism as a means of co-ordinating the actions of individual agents within the economy. While the political economy of the old classical economists had been primarily concerned with questions concerning the causes and process of economic growth, the neoclassical or marginalist economics which came to dominate the scene towards the end of the nineteenth century concentrated much more narrowly on the optimising behaviour of individual agents.

The defining characteristic of marginalist theory is to represent economic problems as issues of optimal choice. This approach resulted from the deliberate application of mathematical reasoning to economic analysis - bringing to economic theory the notions of marginal increments and optimisation through marginal adjustment. Individual agents within the economy, be they consumers or producers, are depicted as engaging in acts of rational choice, balancing marginal benefit against marginal cost. The activities of these rational optimisers are understood to be co-ordinated through the price mechanism. Markets are presumed to clear, establishing an equilibrium state from which, in the given circumstances, no one has any incentive to depart. The marginalist analysis is thus focused on the attainment of equilibrium through the working of the market mechanism; correspondingly, the solution of a problem - the elimination of some disequilibrium situation - is characteristically envisaged in terms of "getting prices right".

Initially neoclassical economists, concentrating on microeconomic matters, gave relatively little attention to macro problems, but by the 1920s and 1930s an intensive discussion of 
macro issues had developed. With respect to the employment issue, the old Ricardian contention that the natural state of the economic system was one of full employment was carried through into the new era, but now with a neoclassical twist. The rationalisation brought forward to justify the thesis that the value of planned demand naturally tends to equality with the value of output produced was that it is the proper functioning of the price mechanism which ensures equality of planned investment with savings out of full employment income. Specifically, it was held that the rate of interest served to equate savings and planned investment. Establishment of the "natural" rate of interest would ensure equilibrium in the savings-investment (loanable funds) market, guaranteeing the recirculation as effective demand for output of whatever portion of current income was reserved as savings. In that situation saving becomes equivalent to consumption as a source of demand. Keynes (1936, p.19) quotes Marshall to that effect:

The whole of a man's income is expended in the purchase of services and of commodities. It is indeed commonly said that a man spends some portion of his income and saves another. But it is a familiar economic axiom that a man purchases labour and commodities with that portion of his income which he saves just as much as he does with that he is said to spend. He is said to spend when he seeks to obtain present enjoyment from the services and commodities which he purchases. He is said to save when he causes the labour and commodities which he purchases to be devoted to the production of wealth from which he expects to derive the means of enjoyment in the future.

Thus, in the neoclassical era, as had not been the case in classical times, the balancing of savings and investment was recognised as potentially problematical, but it was believed that the efficient operation of the price mechanism - in the form of the "interest rate mechanism" - would (eventually) resolve any problem which might arise. It was accepted however that this mechanism did not work with perfect efficiency. Neoclassical writers (e.g. Wicksell, Pigou, D.H. Robertson, and the early Keynes) held that slow operation of the interest rate mechanism permitted short-term variations in employment and output. If, for instance, a change was perceived in investment prospects, the natural rate would alter to maintain equality between savings and investment. The trouble was that the actual rate which obtained in the market, and to which agents responded, was the "money" rate as set by the banks; if the banks were slow in adjusting their rate to the change in investment conditions, the money rate would fail to move with the natural rate, resulting in an excess or deficiency of investment spending above or below savings. The understanding was that an excess of intended investment over savings would induce increased bank lending; alternatively, if savings exceeded investment, the money supply would fall. Spending, it was supposed, would vary with changes in the quantity of money.

What happened next, following an increase or decrease in spending, would depend on the degree of money wage and price flexibility. If, with full flexibility, all money values responded immediately and proportionately to the monetary change, the price level would 
alter without any impact on output and employment. But if, as was considered more likely, commodity prices altered more quickly than money wages, real wages would be affected, resulting in changes in employment and output. In time, of course, once the money rate caught up with the natural rate and real wages were restored to their "proper" value, activity would return to its normal level. The cyclical unemployment associated with such a sequence of events could therefore be classified as frictional attributable to slow adjustment of the rate of interest ("the price of capital") and slow adjustment of the money (and, so it was believed, real) wage rate (the price of labour).

In the inter-war period, however, it became evident to Professor Pigou that the abnormally high and prolonged unemployment then being suffered in Britain and elsewhere across the industrial world represented something other than the regular fluctuations of the trade cycle as experienced in earlier years. Temporary malfunctioning of the interest rate mechanism did not seem sufficient to account for the current problem of persisting unemployment. But Pigou still interpreted the situation as a problem with prices - specifically the price of labour services. His diagnosis (presented in his 1933 Theory of Unemployment) was that the distressing contemporary situation could be understood only as the result of an unduly (and persistingly) high level of real wages; Pigou (1933, p.256) surmised that, after the dramatic changes in prices and money wages during the war and immediate post-war years, the level of money wages (and so real wages) had got "stuck" in an inappropriate relationship to the level of commodity prices.

Since the post-Armistice boom, however, the unemployment situation has been very different from what it was before the war. Instead of a percentage of unemployment amounting, on the average of good and bad years, to some $41 / 2$ per cent, post-war unemployment has moved from a mean from twice to three times as large as this. This circumstance suggests strongly that the goal of long-run tendencies in recent times has been a wage level substantially above that proper to nil unemployment, and that a substantial part of post-war unemployment is attributable to that fact.

In other words, workers, maintaining the going level of money wages (and with these, real wages), were pricing themselves out of employment. The consequent unemployment could be described as being, in effect, "voluntary". The remedy proposed was, in modern parlance, "to get prices right" by engineering a cut in real wages. Pigou, apparently taking it for granted that the interest rate mechanism would, in principle, ensure equality of planned spending with the value of output produced (i.e. tacitly subscribing to Say's Law) was confident that employment would then increase as, with lower wages, firms would move down their "labour demand" (marginal product of labour) schedules.

As to the practicability of this strategy, careful assessment of production conditions led Pigou (1933, p.106) to the conclusion that what he called the "real demand function for labour" was fairly elastic, implying that no very great reduction in real wages was required to boost employment to a satisfactory level. 
... we may, therefore, not unreasonably put the elasticity of the money demand for labour in times of deep depression at not less numerically than -1.5 . . . . We have thus margin enough for a fairly confident claim that, in times of deep depression, after an interval not less than the period of production of the generality of wage-goods and export goods, an all-round cut of 10 per cent in money rates of wages ${ }^{2}$ would lead, other things being equal, to a more than 10 per cent expansion in the aggregate volume of labour demanded, and so, apart from unfilled vacancies, in the volume of employment.

It was specifically on Pigou's Theory of Unemployment, and his diagnosis that the root of the trouble lay in the labour market - stickiness of real wages being responsible for the continuing high unemployment of the period - that Keynes set his sights as constituting the fullest and most explicit statement of what he understood to be the "classical" position.

\section{The Keynes theory}

By the mid-1930s Keynes had eventually arrived, in his own mind, at an understanding of what was wrong with the traditional approach and what was needed in its place. As Keynes saw the situation, the classical theory had failed to provide a believable explanation of the major contemporary economic problem - the high and persisting unemployment affecting Britain and other industrial countries. The classical theory was, in his opinion, incapable of comprehending the true nature of the trouble.

In addition to "frictional" unemployment, (the classical theory) is also compatible with "voluntary" unemployment due to the refusal or inability of a unit of labour, as a result of legislation or social practices or of combination for collective bargaining or of slow response to change or of mere human obstinacy, to accept a reward corresponding to the value of the product attributable to its marginal productivity. But these two categories of "frictional" unemployment and "voluntary" unemployment are comprehensive. The classical postulates do not admit of the possibility of the third category which I shall define ... as "involuntary" unemployment. ${ }^{3}$

\footnotetext{
${ }^{2}$ It should be emphasised here that Pigou of course held that employment was a function of the real wage; in keeping with that understanding, by this stage in his argument he had already attempted to take into account "what changes in rates of real wages are implied by given changes in money wages". (Pigou, 1933, II, x). He concluded that the required changes in money wages were not too large to be feasible.

${ }^{3}$ Keynes's famously obscure definition of involuntary unemployment (1936, p.15) reads thus: "Men are involuntarily unemployed if, in the event of a small rise in the price of wage-goods relatively to the money wage, both the aggregate supply of labour willing to work for the current money-wage and the aggregate demand for it at that wage would be greater than the existing volume of employment". The essential point is that (in terms of the labour-market diagram) Keynes envisages, with deficient demand and unemployment, a difference (diagramatically, a gap) existing, at the going full-employment rate of wages, between the
} 
Keynes's explanation of the occurrence of involuntary unemployment depended on his identifying aggregate demand for output, not conditions of labour supply, as the key determinant of levels of output and employment within the economy. Aggregate demand was no longer treated as a "tame" variable, ultimately tied to the value of output supplied. If there happened to be insufficient demand within the system to justify full employment, workers would find themselves, against their wishes, out of a job, even if the terms on which they sought work were perfectly compatible with their employment under other conditions of demand. Demand for labour is derived demand. The problem was not, as Pigou viewed it, one of wages being stuck at an inappropriate real level, but the quite different one of insufficient planned demand for output.

In the General Theory Keynes emphatically made the point that unemployment was not due to excessive real wages - employment (or the lack of it) depended on the demand for the product, not on the wages paid to labour. In fact, if there was a relationship between real wages and employment it actually ran, he argued, in the opposite direction from that supposed by the conventional theory. What Keynes suggested was that when firms cut back on production, laying off workers, these firms move leftwards down their short-run supply curves, so that if prices were then falling, with no change in money wages, the cost of living would consequently be falling and real wages rising. It was the emergence of unemployment that was responsible for the increase in real wages, not vice versa. From Keynes's perspective any such increase in wages was no more than a natural and incidental consequence of industrial contraction; it, categorically, was not the cause.

A year or two later Keynes (Keynes, 1939) was able to eliminate from his analysis this potentially confusing association of changes in employment with changes in wages. It appeared, according to empirical evidence, that when employment fell, prices did not move relative to money wages as he (relying on conventional neoclassical theory) had supposed. Thus, if real wages did not in fact increase as employment fell, it was should now be unambiguously clear - even to the most dyed-in-the-wool classical observer - that unemployment was occurring simply and directly because want of demand for the product of labour meant want of demand for the services of labour. Wages didn't come into it. Thus Keynes severed a conventional theoretical link between employment and the price of labour, directing attention away from wage inflexibility to the state of demand in the markets for the produce of labour.

In the Keynes theory the adequacy of intended aggregate demand for output is the key strategic variable. Keynes rejected both the rationalisations previously offered for not worrying about the adequacy of aggregate demand. He saw demand as independent of supply, as an unstable and unreliable factor reflecting the expenditure plans of consumers 
and investors: there was no guarantee, as old authorities such as Ricardo and J S Mill had supposed, that the very act of production implied demand - that the value of planned expenditures would naturally and automatically match the value of output produced.

Fundamental to Keynes's "general theory" is his appreciation that the economy exists and functions within real historical time, implying that wealth-seeking agents must necessarily make decisions respecting asset choice under conditions of uncertainty. Uncertainty, as faced by decision- makers in the real world, cannot generally be reduced to calculable, and insurable risk. This, in Keynes's opinion, was a fundamental matter which his predecessors had got wrong. Thus Keynes (1937), differentiating his conception of the situation from that of the "classics" (present and past), argued that his contemporaries:

... like their predecessors, were dealing with a system in which the amount of the factors employed was given and other relevant facts were known more or less for certain. This does not mean that they were dealing with a system in which change was ruled out, or even one in which the disappointment of expectation was ruled out. But, at any given time, facts and expectations were assumed to be given in a definite and calculable form, and risks, of which, though admitted, no much notice was taken, were supposed to be capable of exact actuarial computation. The calculus of probability, though kept in the background, was supposed to be capable of reducing uncertainty to the same calculable status as certainty itself;

And he goes on to charge "classical" economic theory with being

... one of those pretty, polite techniques which tries to deal with the present by abstracting from the fact that we know very little about the future.

That the General Theory is macroeconomics for a world of uncertainty is evident from the importance Keynes attributes to expectations and states of confidence as affecting the behaviour of decision makers, as regards both choice amongst financial assets and the purchase of produced commodities. The fact that decisions have to be made without decision-makers being sure of the eventual outcome is central to Keynes's vision of the working of the system: the economy is viewed not as a closed mechanical system, but as one which is "open-ended" in that there can never exist a complete set of markets such that all risks and uncertainties are eliminated by insurance; hopes and fears, imagination and guess-work cannot in the real world be excluded as determining factors in the working of the economic system. Investors may prefer to retain liquidity, rather than commit resources to projects whose prospects are deemed too doubtful. Demand for output, depending on all these subjective and unstable factors is likely to be subject to periods of optimism and depression, of boom and slump. 
Nor was it the case, Keynes argued, that reliance could be placed on the neoclassical notion of the "interest rate mechanism" as a means of reconciling current savings and intended investment at a full employment level. According to his new theory of liquidity preference, the role of the rate of interest (a monetary, not a "real" phenomenon) was to reconcile asset preferences and demands in the financial markets, and not to equate the value of spending on new capital goods with the value of saving. [We can add that the neoclassical "productivity and thrift" treatment of interest as equating the demand and supply of (new) "capital" is undermined by the "Cambridge critique" which demonstrates that to attempt to explain in these terms the rate of interest ("the price of capital"), as equal to the marginal product of capital, is logically incoherent.] The traditional neoclassical mechanism of macroeconomic equilibration via price (interest rate) adjustment was thus ruled out of court.

A possibility of escape from depression via a general fall in prices (and increase in the value of money) was mooted, notably by Professor Pigou, and indeed by Keynes himself in the General Theory, neither of whom however were optimistic as to the activity-boosting implications of general deflation. We return to this issue below, but for the moment note Keynes's own thoughts on the matter.

Keynes considered carefully the question of whether downward wage and price flexibility would help to get the economy out of a demand-deficient state of slump. From his perspective, any mechanism to counter unemployment would have to work via a stimulus to demand: he concluded that neither real wage reductions (even if such could be achieved), nor falling money wages and prices, would help; either would probably make the situation worse. The economy could not, he believed, be regarded as possessing an automatic and reliable "self-righting" capability: government intervention, possibly in the role of "pump-priming”, was indicated as necessary to get things moving.

He explained his reasons for favouring price stability over deflation in recession conditions (1936, pp.269-70):

. . . if labour were to respond to conditions of gradually diminishing employment by offering its services at a gradually diminishing money-wage . . . [t]he chief result of this policy would be to cause a great instability of prices, so violent perhaps as to make business calculations futile in an economic society functioning after the manner of that in which we live. To suppose that a flexible wage policy is a right and proper adjunct of a system which on thw whole is one of laissez-faire, is the opposite of the truth. . . . In the light of these considerations I am now of the opinion that the maintenance of a stable level of money-wages is, on a balance of considerations, the most advisable policy for a closed system; whilst the same conclusion will hold good for a open system, 
provided that equilibrium with the rest of the world can be secured by means of fluctuating exchanges. There are advantages in some degree of flexibility in the wages of particular industries so as to expedite transfers from those which are relatively declining to those which are relatively expanding. But the moneywage level as a whole should be maintained as stable as possible, at any rate in the short period.

Again, as an emergency means of macro stabilization, another form of price adjustment is from the Keynesian position - firmly rejected.

Thus, to sum upon the Keynes perspective: Keynes accepted none of the three forms of price adjustment traditionally expected (or more recently proposed) as means of ensuring full employment within the economy. The idea of the so-called "interest rate mechanism" reflected a misconception about the nature and role of the rate of interest: interest rate adjustment could not therefore be expected to ensure maintenance of the incomeexpenditure flow at the full-employment volume. In the labour market demand for labour should be seen as derived demand - depending on conditions in the product markets, not simply on the real wage existing in the labour market. Finally, in Keynes's considered opinion, a general deflation of money wages and prices could not be regarded as a practical route to recovery from recession. A set of prices Keynes did regard as critical in determining levels of output and employment were the values attached by entrepreneurs to new producers' goods in which they might invest. The problem with these was that such valuations, depending on unstable and unreliable factors of confidence and expectations, were likely to be variable, and independent, in the sense of there being no reason that they should correspond to the volume of investment spending which would match savings out of the full employment level of income.

\section{After Keynes}

The Keynesian theory pretty quickly became established (at least for the next thirty plus years) as the new orthodoxy: a completely novel body of economic analysis - modern macroeconomics - developed. Prominent in this new literature was the Hicks-Hansen IS/LM model which, integrating the income-expenditure and monetary elements of Keynes's system in a convenient diagram, was generally accepted as satisfactorily representing the essentials of the Keynesian conception. Until the late 1960s, Keynesian theory, although not unchallenged, formed the basis of mainstream macroeconomics.

What challenges to mainstream Keynesian orthodoxy that there were in the early years, although coming from sometimes hostile traditionalists, nevertheless implied acceptance of the essential Keynes proposition that aggregate demand was what mattered with respect to the determination of output and employment. The fact that attention was directed to the determination of demand rather than, as in previous times, to the level of real wages or to 
disparity between the "natural" and money rates of interest indicated just how generally and profoundly thinking had been changed by the publication of the General Theory.

One line of criticism built on the notion of the "wealth" or "Pigou effect" as providing a possible automatic rescue-mechanism - the relevance of which (as noted above) Keynes had denied - for an economy sunk in heavy unemployment. The argument was that lower prices would increase the real value of the nominal money stock, thus generating a positive wealth effect on household spending; if, the argument went, prices could fall far enough, then aggregate demand would be boosted to full employment level, regardless of any liquidity trap or of interest inelasticity of investment demand. While this purely notional adjustment mechanism featured in the textbooks, it was however explicitly recognised by theorists who explored this real-balance route (Pigou himself, Patinkin ${ }^{4}-$ not to mention Keynes) that the weakness of the wealth effect on consumption, and even more importantly, the damaging expectational effects on demand likely to result from a process of deflation, ruled this effect out of court as a practical equilibrating mechanism. It was agreed that downward adjustment of money wages in a depression might very well make things worse rather than better. The Japanese experience of deflation in recent times ought to have disabused armchair theorists of any idea of recommending deflation as a cure for unemployment. ${ }^{5}$ But nevertheless, despite all past discussion and recent practical experience, the idea of deflation as a stimulus to demand has currently been brought back into mainstream macro teaching, in a central role, via use of the fashionable AD/AS model (of which more below).

\footnotetext{
${ }^{4}$ We may quote Patinkin (1959, pp.582-87) on this: "The automatic adjustment process of the market is too unreliable to serve as the practical basis of a full-employment policy. In other words, though the real balance effect must be taken account of in our theoretical analysis, it is too weak - and, in some cases (due to adverse expectations) too perverse - to fulfil a significant role in our policy considerations.
}

5 Reason to be skeptical of the argument that a process of deflation can have a positive effect on demand and employment is furnished by recent experience in Japan, where falling prices have not rescued the economy from recession. Thus J H Makin (2006) an informed observer of the Japanese science writes:

Deflation is dangerous. The nightmare of a deflationary spiral arises from the fact that as deflation intensifies and prices fall more rapidly, the real cost of borrowing rises. With a zero interest rate and 1 per cent deflation, the real cost of borrowing is 1 per cent. If deflation intensifies to 2 per cent, while the demand to hold cash strengthens because the rise in deflation represents a rising, risk-free, tax-free return on cash, more cash will be demanded. The move into cash further depresses spending, and thereby further intensifies deflation. The real cost of borrowing keeps rising, imparting an accelerating drag on the economy. . . . As noted, a deflationary spiral produces a sharp increase in the demand for liquidity that, if not satisfied by the central bank, will be satisfied by households and businesses selling goods and services, thereby intensifying the deflationary spiral. 


\section{Walrasian macroeconomics}

Keynes's understanding that the elimination of unemployment is not simply a matter of "getting prices right" can - perhaps surprisingly - be supported by an implication of what we may call "Walrasian macroeconomics". The point can be made, as it has by Michio Morishima, the distinguished Japanese economist, that, in a Walrasian-type macroeconomic model, more than flexibility of prices is required to guarantee full employment. Even if prices are fully flexible, that may not be enough to ensure that the system will naturally tend to equilibrium at full employment. His argument is concerned not with the stability of equilibrium (whether the system if upset will return to equilibrium), but to a question not normally raised - the existence of equilibrium (the existence of a set of values at which all markets in the system can be simultaneously in equilibrium). Let us examine first of all the characteristics of a "Walrasian macro model" and then turn to Morishima's (rather neglected) thesis.

Over the last seventy years the Walrasian general equilibrium model has been adopted by neoclassical theorists as the most appropriate conceptualisation and representation of the economic system. The neoclassical synthesis of the 1950s and 1960s was an attempt to combine Keynesian and Walrasian contributions; the simplified macroeconomic version of the Walrasian s ystem employed in Patinkin's (1965) Money, Interest and Prices exemplifies this approach. Let us make use of such a model, employing it specifically to shed light on the question of whether the attainment and maintenance of full employment is in fact a matter of "getting prices right".

First of all, recall the nature of the Walrasian general equilibrium model. The Walrasian model shows the economy as a system of inter-related markets, this system being represented by a set of simultaneous equations which state the conditions to be satisfied for equilibrium demand equal to supply, or excess demand equal to zero in all markets. Excess demand in each market is taken to be a function of the price in that market and of all other prices. Two questions are posed: does a set of prices exist which yields simultaneous equilibrium in all markets (the issue of the existence of equilibrium)? And, secondly, if such a set of equilibrium prices does exist, will the market mechanism succeed in establishing these prices (the issue of the stability of equilibrium)?

Take a very simple illustration of the nature of the general equilibrium model. Suppose there are $\mathrm{n}$ goods traded within an economy - specifically 5 goods (in reality there would of course be thousands) - call them goods a, b, c, d and e. If we take one of these as the numeraire and set the price of one unit of that good at unity (Pe, say, equals 1 ), there are then $\mathrm{n}-1$ (4) relative prices - $\mathrm{Pa}, \mathrm{Pb}, \mathrm{Pc}$ and $\mathrm{Pd}$ in terms of good $\mathrm{e}$ - to be determined. There are at the same time n (5) equilibrium conditions ( $\mathrm{XD}$ equations) to be satisfied. It might at first sight appear that we have more determining equations than unknowns (5 as against 4). In fact, by "Walras' Law" we actually have only $\mathrm{n}-1$ (4) independent excess demand equations - the same number of equations as unknowns. Conventionally 
we take it that, with equality in number of unknowns and independent determining conditions, it is reasonable to suppose that a solution - a set of prices which yields marketclearing equilibrium - exists. ${ }^{6}$ (Furthermore the normal presumption is that price adjustment will establish that set of equilibrium prices.)

Let us now reformulate this simple model as a macro model. ${ }^{7}$ Again suppose that there are 5 markets within the system - but now assume that these are markets for consumption goods (C ), capital goods (K), labour (L), bonds (B) and money (M). It is assumed that the given stock of money consists of a certain number of nominal units. Taking money as the numeraire, the unknowns are 4 relative prices (of C, K, L and B) expressed in terms of money. (When these 4 prices are specified the value of the money supply, in terms of a bundle of goods, M/P is implied.) To determine the 4 unknowns, there are, by Walras' Law, 4 independent excess demand equations amongst the 5 excess demand equations of the system. Thus we may conclude that it is reasonable to suppose the existence of an equilibrium set of prices. (Furthermore, and again following convention, we may suppose that the price mechanism works in such a way as to establish that set of prices if equilibrium has for any reason been disturbed.) Thus, the model we have here is, in conventional neoclassical terms, read as representing a macro system in which price adjustments should be capable of establishing full employment equilibrium. If this is taken as a parable with something to say about the real world, the moral would seem to be that, with a properly functioning price mechanism, full employment may be regarded as the natural state of the economy (the corollary being, of course, that persisting disequilibrium must be due to inflexibility of prices).

The above model - employing the Walrasian conception in the macro context - simple though it is, essentially represents the neoclassical view of the functioning of the macroeconomic system. That is the conception of things which underlies the almost

\footnotetext{
${ }^{6}$ As equality of unknowns and independent equations does not in fact guarantee a solution, "we have to abandon the confidence of Walras for the much less certain hope that there is a unique solution". (Johnson, 1971, p.103) That is certainly the usual procedure. Thus Patinkin (1965, p.37): "Now, equality between the number of unknowns and the number of independent equations is neither a necessary nor a sufficient condition for the existence of a solution. Nor does it ensure that solutions, if they do exist, will be only finite in number. For our purposes, however, these highly complicated issues can be ignored. Instead, we shall accept such equality as justifying the reasonableness of the assumption that one and the same [unique] set of money prices can simultaneously create equilibrium in each and every market."
}

\footnotetext{
${ }^{7}$ Note E R Weintraub (1974, p.15): "In a real sense, macroeconomics is general equilibrium theory with some of the many markets grouped together for expositional clarity and convenience. In a general equilibrium schema of about 80,000 markets describing the behaviour of all prices within the economy, perhaps the first 40,000 markets are for consumer goods, the next 20,000 for capital goods, with 10,000 for labour services, 10,000 for financial assets, and a few for money. Combining markets for similar goods there is "merely" the proble of five markets: consumer goods, investment goods, labour services, financial assets, and money".
} 
universal textbook assertion that the Keynesian explanation of unemployment must reside in price rigidity, that underlies the New Classical and Rational Expectations accounts of (what are said to be at most) temporary deviations from the Natural Rate of Unemployment, and indeed underlies the concern of the (so-called) "New Keynesian" school with the causes of price stickiness or price rigidity. All these several varieties of macroeconomic theorising share the characteristic neoclassical belief - perhaps "faith" would be a better word - that the achievement of full employment equilibrium is a matter of "getting prices right". But is it?

Consider again our simple Walrasian macro model and imagine that initially the situation is one of full utilisation of production capacity and full employment. Now suppose there occurs a fall in the demand for capital goods. If demand remains low, producers in that sector will reduce production and cut employment and, as incomes fall, the recession is transmitted via the multiplier process throughout the economy. In terms of the IS/LM model the IS curve (and possibly the LM curve as well) has moved to the left and the economy settles to a new equilibrium with production adjusted to the reduced level of aggregate demand and less labour employed than is available. The sum of excess demands is then less than zero: demand equals supply in the goods and asset markets, but supply exceeds demand in the labour market.

The condition of net excess supply poses a theoretical problem: by Walras' Law that state of affairs is an impossibility - the sum of excess demands ought to equal zero. If, in the C, K, B and M markets excess demand is zero, then, according to Walras' Law, demand and supply must be equal in the remaining market - i.e. there must be full equilibrium in the labour market. The logic of the conventional analysis rules out the occurrence of this situation of depression equilibrium - the existence of an excess supply of labour should necessarily imply the simultaneous existence of an equal value of excess demand for goods or securities which would directly or indirectly justify increased production. But in reality we can readily envisage such "slump conditions" in which labour is unemployed while demand equals supply everywhere else in the system. Potential demand for goods has "evaporated" into a desire for liquidity. Walras' Law evidently doesn't square with that perception.

The possible emergence of a net excess supply of labour was picked up by Robert Clower (1965) and Axel Leijonhufvud (1968) thirty odd years ago when attempting to capture the essence of Keynes's general theory within a Walrasian framework. Clower's explanation of the occurrence of such an excess supply of labour - contradicting the prediction of Walras' Law - was that in a money-using economy planned or "notional" demand will not become "effective" demand if, because of lack of access to means of payment, agents are unable to express their intended demand on the market. In Clower's example unemployed labour has an unsatisfied demand for commodities but, with sales of labour services constrained and a consequent want of current income, does not have the necessary means of payment to make its demand effective. If, as in the Clower 
illustration, the real wage is stuck at too high a level, there exists simultaneously an excess supply of labour and a notional excess demand for goods, but without any actual pressure of demand in the goods market to raise prices relatively to money wages. The conclusion reached was that, under disequilibrium conditions, Walras' Law does not hold good: while it is true that taking notional and effective excess demands together the sum of excess demands does equal zero, with respect to effective demand alone as actually expressed in the market, the general case is that sum of excess demands is, at most, equal to zero. With disequilibrium, net effective excess demand can be negative. Thus, it would appear, the conventional Walrasian model fails to comprehend the constraint on effective demand which exists in the circumstances of Keynesian "underemployment equilibrium".

On that basis, recognition of the possibility of negative net excess demand (net excess supply) emerging within the economic system was taken by Clower to be the crucial feature which differentiates Keynes's theory from conventional neoclassical theory Clower argued that, even though Keynes framed his analysis in Marshallian rather than Walrasian terms, that in effect was the proposition he was advancing - that total excess demand within the economy did not necessarily sum to zero, implying that, with unemployment, the potential equilibrating force of positive excess demand need not in fact be operating to propel relative values towards a configuration consistent with full employment equilibrium.

What do we make of this interpretation of the nature of Keynes's theoretical innovation? As we read it, Clower did not get to the root of the matter: he seems to have focused on a symptom rather than on the cause of depression conditions as understood by Keynes. What Clower has formally identified - in terms of Walrasian theory - is simply the multiplier phenomenon, which derives from the fact that if labour is thrown out of work, purchasing power is reduced and workers' effective demand for goods and services is thereby constrained. The Clower reading of Keynes has nothing to say about the cause of such a state of affairs - there is no consideration whatever of the reason why, in the first place, workers may have been laid off by their employers. The fact that the remedy as envisaged by Clower - a reduction of real wages - is the same as that proposed by Pigou suggests that Clower had not, as he claimed, put his finger on the distinctive feature of Keynes's analysis of unemployment. Clower may have introduced the Keynesian multiplier to the Walrasian system, but there is much more than the multiplier in the General Theory.

The state of affairs envisaged by Clower - an economy stuck in unemployment because real wages are fixed too high for full employment - does in fact (whatever may have been intended) correspond to Pigou's picture of unemployment equilibrium. If we consider how such a Pigouvian situation would appear in Walrasian terms, we shall find a pointer to how the Keynesian conception may more adequately be represented in Walrasian terms. Pigou takes it for granted that when production is offered on the market, demand (temporary, frictional difficulties aside) must be sufficient to take up whatever output is 
produced by labour of which the marginal product does not fall short of the real wage. (That is certainly the implication of treating, a la Pigou, the labour market exactly as the market for any final commodity, with equilibrium determined at the point of intersection of the demand and supply curves.) By Walras' Law, when (in equilibrium) the sum of excess demands equals zero, the situation in any one market of the economy can be inferred from the conditions prevailing in the rest of the system. Thus, if it happens to be the case (thinking of our 5 market model) that demand equals supply in the $\mathrm{C}, \mathrm{B}, \mathrm{M}$ and L markets (full employment), demand must also equal supply in the $\mathrm{K}$ market. From the Pigouvian perspective, so long as labour market conditions (specifically the terms of labour supply) remain unaltered, demand for output has to stay fixed at the full employment level. If, as Pigou represents the situation, employment is determined (ceteris paribus) in the labour market by conditions of labour supply, there is simply no room for an independent investment ( $K$ demand) function.

Evidently, Clower has not succeeded in translating the Keynes theory into Walrasian terms. The thesis we are about to develop as to how the Keynes theory should be interpreted in terms of the Walrasian framework, a thesis which questions not the stability of equilibrium in the case of a multi-market economy, but raises doubt regarding the very existence of an equilibrium set of values, derives from the original and important, but regrettably neglected, contribution by Michio Morishima (1977). Morishima directs attention to the possible indeterminacy of the system, on account of there existing more conditions of equilibrium than can simultaneously be satisfied.

We have noted that Clower's attempt to connect the Keynesian and Walrasian models seems, though presumably that was not what was intended, to have landed us back in the theoretical conception of Professor Pigou. Let us see if we can find instead a Keynesian perspective. If, to break out of the Say's Law world implicitly assumed by Pigou, we introduce an independent investment function into our 5 market Walrasian system, the situation is significantly altered. It can no longer be assumed that if conditions are as specified in the $\mathrm{C}, \mathrm{B}, \mathrm{M}$ and $\mathrm{L}$ markets, the state of affairs in the $\mathrm{K}$ market is also determinate: we are now allowing the $\mathrm{K}$ market to go its own way - for the demand for $\mathrm{K}$ goods to reflect investors' views of the future, for their expectations and confidence to determine the orders placed, rather than for the volume of these orders automatically to correspond to the output available from the K goods industry. There is now an "un-tamed" aggregate investment function; consequently we now have 5 independent equilibrium conditions to determine the 4 unknowns (relative values) within the economy. The system is overdetermined. ${ }^{8}$ It is now possible that the volume of planned investment spending

\footnotetext{
${ }^{8}$ If it is "reasonable" to suppose that, with an equal number of independent equations and unknowns, that a solution exists, it may be correspondingly reasonable to doubt the existence of a solution when the number of independent equations exceeds the number of unknowns."[If, with more equations than variables, the equations are linear and independent, they cannot be consistent.] If the equations are linear and inconsistent ...
} 
corresponding to the forecasts and valuations of investors and may not be such as to, at the same time, take up the resources left available for investment by demand elsewhere in the economy. That being so, there may be no solution to be found by price adjustment; if the system is overdetermined and no equilibrium set of prices exists, no matter how flexible wages and prices may be, there is no guarantee that unemployment can be eliminated through the free functioning of the market mechanism. ${ }^{9}$

If that is so, the root of the problem lies not in imperfect working of the price mechanism, but more deeply - in the existence of a fundamental inconsistency within the economy. It is not that price stickiness is preventing the emergence of the set of prices which would ensure full co-ordination of all plans within the economy to produce, consume, save and invest. Rather, the parameters of the system are incompatible: that is to say, it is perfectly feasible that current plans to sell labour services and current plans to purchase commodities, including the purchase of new producers' goods, are simply irreconcilable.

Without significant revision of investors' expectations, state of confidence and spending plans, price changes, reflecting market imbalances, will not bring equilibrium.

The prices - valuations - of assets, both real and financial, themselves may in fact be anything but sticky, all the time reflecting changes in the multifarious factors affecting the views of asset holders and investors, but there is nothing in the system to ensure that the resulting investment demand function (or aggregate demand function) automatically falls into line with the notional equilibrium investment (or aggregate) demand function which would be implicit in a closed Walrasian system. The point is that these asset values are free to respond to all the considerations in the minds of asset holders and investors - they are not fixed, as would be required by Walras' Law (or Say's Law) in order that investment spending exactly matches savings made out of current income.

Thus, freeing aggregate demand from the constraint of Say's Law (as represented by the supposition of a "tame" investment function), we can no longer presume the existence

then there is no solution. If the equations are not all linear, no general statement can be made." From C F Christ, "An aside on counting variables and equations in systems of simultaneous equations", quoted by H G Johnson.

${ }^{9}$ Morishima (1977, p.95), observes that a "neoclassical full employment" situation is based on the assumption that "aggregate investment is perfectly flexible; that is to say the system lacks a non-trivial investment function, whereas it has a well-defined savings function. . . . It is really because of this lack of an investment function that investment can smoothly and quickly be adjusted to savings in our model and not vice versa. Such an economy, with perfectly flexible investment, is said to satisfy Say's law. With this law, there is no obstacle to full employment equilibrium. It is indeed because of the premise of Say's law that neoclassical economists could be confident of full employment equilibrium; therefore, it was a prime target of Keynes' attack. In fact, he rejected the perfect flexibility of investment by introducing an investment function; then he found that the system was over-determined and full employment was not attainable." 
of a solution in the form of a set of market-clearing prices. Price flexibility is not then the key to the attainment of full employment equilibrium. What is critical is the consistency of the parameters - in the Keynes case, of the planned volume of effective demand with production capacity.

Morishima (1977, pp.115-6) compares (in effect) the Pigouvian and Keynesian visions:

Suppose . . . that Say's Law is true. Then there exists a neoclassical fullemployment, full-capacity equilibrium. Even in this case, if the wage is set [above the full-employment level], then no forces work to move the economy towards the equilibrium, because of the downwards rigidity of the wage rate. That is to say, the neoclassical equilibrium is prevented from prevailing in spite of its existence. If this were the case, we might ascribe the causes of unemployment to the downwards rigidity of wages and hence to the trade unions. Keynes, however, opposed this view; he believed that the neoclassical full- employment, full-capacity equilibrium does not exist, because investment is determined independently of savings and, therefore, even if the wage is perfectly flexible, the economy cannot settle down at any point because of the overdeterminacy. Only the downwards rigidity stops this endless fluctuation, but is not the cause of under-employment because the removal of it will not lead to full employment. . . . Keynesian unemployment is the particular unemployment which corresponds to that level of savings which equals the level of investment independently determined.

The reason why the investment demand function must (in a realistic context) be treated as independent - and not automatically consistent with full-employment savings - is that investment decisions are - a central point of the Keynes theory - made under conditions of uncertainty. This means irreducible uncertainty, not risk such as can be covered by insurance. If the uncertainties respecting the returns to be got from investment could be eliminated by forward trading or insurance, then there would never be any case from holding back from investment so long as the physical conditions of production were capable of yielding profit. But if there is no way of ensuring that all possibilities of loss are excluded by making suitable arrangements, then investment must depend on the subjective factors - expectations, confidence in these expectations, hopes and fears - that enter into the investor's decision- making. Agents have to make up their own minds as to the best course of action, and the outcome may well, ceteris paribus, not correspond with what is required for full employment.

This is the point at which we come up against the fact that economics is, as Keynes regarded it, a "moral" science and not a natural science: the investor's decision is a human decision and should not be treated as a link in a purely mechanical sequence 
whereby whatever resources are left aside from current use are automatically channelled to investment. ${ }^{10}$

Frank Hahn (1982), discussing the implications for the Walrasian general equilibrium system of allowing for uncertainty, makes in effect the same point - that in a Keynesian world, in which expectations play a critical role, the attainment of full equilibrium cannot be guaranteed. He points out that the existence of irreducible uncertainty means that a complete set of markets, such that the entrepreneur can eliminate all possibility of loss, will not exist. The consequences are serious: "if the invisible hand is to operate there must be sufficient opportunities for intertemporal and contingent intertemporal trade. . . The lack of contingent markets means that the market economy is associated with more uncertainty than pure theory allows. The lack of intertemporal markets means that great weight must rest on market expectations." In such circumstances the system is, rather than being completely interdependent, "open-ended" in that the outcome (the state of the economy) depends on subjective, essentially independent rather than internal factors. Hahn remarks that "Keynes ... placed great emphasis on the fact that he did not invoke [the complete markets postulate]".

The significance of our investigating in terms of the Walrasian framework the implications of the Keynes theory is that it becomes formally evident that in the case of a multimarket economic system operating in real world conditions of uncertainty, there can be no guarantee that in all circumstances an equilibrium solution (in the form of a marketclearing set of prices) actually exists. In a world of uncertainty asset values, incompatible with the rest of the system, are generated in reflection of the hopes and fears in the minds of asset-holders. Given such values, asset choices may result in volumes of investment spending and employment irreconcilable with existing intentions to sell labour services. Demand for labour is then deficient. This finding confirms Keynes's message that the degree of wage and price flexibility is not the critical factor to which attention should be directed in the analysis of unemployment. It is of course important that prices adjust to reflect changes in conditions of demand and supply, but it cannot be assumed that price changes - changes in wages or the price level - will be effective in inducing a compensating adjustment of aggregate demand in the event of a general downturn in the economy.

${ }^{10}$ Keynes (1973, p.300): "I want to emphasise strongly the point about economics being a moral science [and not a natural science]. I mentioned before that it deals with introspection and values. I might have added that it deals with motives, expectations,psychological uncertainties. One has to be constantly on guard against treating the material as consistent and homogeneous. It is as though the fall of the apple to the ground depended on the apple's motivation, on whether not is worth falling to the ground, and whether the ground wanted the apple to fall, and on mistaken calculations on the part of rhe apple as to how far it was from the centre of the earth." 


\section{A non-Walrasian framework}

In order to deal with the conventional neoclassical wisdom on its own terms, we have discussed the issue of Say's Law and over-determinancy with reference to a Walrasian-type model. It would however be more appropriate to set the Keynesian argument within the framework of a classical (old-classical) model which is explicitly of a surplus-producing economic system. Using such a framework, exactly the same point can be made with respect to the stability of the income-expenditure circular flow - that rejection of Say's Law calls in question the presumption that full employment equilibrium can necessarily be achieved via price changes which establish a set of equilibrium prices implicit in the structure of the system. Consider the following illustration.

Imagine a simple classical-type surplus-producing economy, modelled a la Sraffa as an input-output system with given technical coefficients, which each period reproduces, with a surplus, the inputs required in production. Suppose that, in total, $\mathrm{n}$ goods and services including intermediate goods, final consumption goods and investment goods - are produced with, as mentioned, output in excess of what is required to replace everything, including the wages of the workforce, used up in the course of production. For equilibrium in the product markets, it is not enough simply that demand equals supply: quantities demanded and supplied must be such that long run equilibrium prices (classical "natural values") obtain with prices which cover costs of production including profit at the going rate. Suppose that a certain supply of labour is offered for employment, and that the rate of real wages is determined by institutional factors at a conventional level. That wage must imply also, given the physical rate of surplus productivity, a determinate rate of realised profit at the full employment level of activity. Suppose too that money (a certain nominal supply being given) is used within the economy as the medium of exchange. We take it that all wage income is automatically spent on consumption goods and that profits are put to the acquisition of new producer goods.

In analyzing the properties of a surplus-producing system of this basic sort and the determination of equilibrium values therein Sraffa abstracted from all Keynesian issues of macroeconomic stability. These were not the questions with which he was concerned. Sraffa supposed incomes - wages and profits - generated in production to be fully expended in purchasing the current output. The situation envisaged is that expenditures on finished wage goods and producers' goods (investment goods) fully recompense the entrepreneurs for purchases of labour services and produced inputs: at the conclusion of the cycle of production all input costs - of materials and of wages and profits (at going rates) have been recovered from sales.

Relative prices, wages and the rate of profit correspond to the specified conditions of equilibrium. If there are $n$ single-product industries in the system there are $n-1$ independent

price-cost equations (comprehending the input-output structure of the system) and one 
extraneously given condition which determines the distribution of the surplus income of the economy (stating either the going rate of profit or, the other side of the coin, the going rate of real wages). For equilibrium demand for labour (directly depending on volume of production in each sector) must also equal the given supply; and (real) money demand (for transactions purposes) be equal to money supply. Thus, again counting equations and unknowns, we have $n+2$ independent conditions/equations to determine $n-1$ relative commodity prices plus either the wage rate $(\mathrm{w})$ or the rate of profit (r), together with equilibrium conditions for labour and money ( $n+2$ unknowns). Thus again, we have a picture of a system in equilibrium, in which a certain number of unknowns are matched by an equal number of determining conditions. Satisfaction of these conditions ensures the internal consistency of the system.

There is no scope in this simple economy for the occurrence of any sort of macroeconomic disequilibrium - for the reason that the agents in this economy are constrained by the rule that all income they receive goes back directly and immediately on the purchase of either consumption goods or producer goods. In each individual commodity market a quantity of output is produced and offered for sale at a price which just covers costs of production including profits. Whether it is supposed that by some past process of trial and error the pattern of production has been adapted to the pattern of demand, we are not informed, and anyhow that is not important: all that matters is that supply is fully adapted to demand. We may say of this situation, with all profits being intentionally spent on new producers' goods, that saving is being matched by planned investment - which, of course, ensures macroeconomic equilibrium. We can further say that intended investment takes up all current savings because, under the circumstances supposed, the agents (capitalists / entrepreneurs?) concerned have no alternative plans. In other words, as far as the capitalist, profit-earning class are concerned, what we might call their (aggregated) investment function is "tame"; that is to say, they (automatically) desire to buy exactly the mix and quantities of investment goods that producers wish to sell. If, in the context of counting equations and unknowns, we drop out one (of the $n$ ) price-cost equation as (by Walras' Law) redundant (leaving $\mathrm{n}-1$ ), we can happily miss out that tame aggregate investment function (comprehending entrepreneurs' demands for capital goods) because, of course, it is well and truly determined by the remaining elements of the system.

Now give our capitalists some say in the matter - allow them to make investment decisions on the basis of the forecasts they make about the profit potential of the investment opportunities they discern, and the hopes or fears with which they make them. If we do this, the aggregate investment function (valuations of produced capital goods) is no longer a "tame" variable which naturally corresponds to the volume of savings available. Some entrepreneurs might wish to invest more, others less than the previously prescribed (hundred per cent) of profits received. The condition of macro equilibrium which was previously satisfied was that overall investment spending exactly matched total saving - now, while that condition of equilibrium remains as before, a new condition has been introduced to the effect 
that intended investment must correspond to the optimal volume as estimated by all entrepreneurs together according to their expectations and confidence - not to their current profit receipts. For any - or all - entrepreneurs the profit-maximising course of action may not be consistent with the alternative course (investing exactly what they save) which would maintain macroeconomic equilibrium. Each agent has freedom to choose his own investment plan. Neither the individual investment functions (nor the aggregated function) are certain to fit into the system as they were before. To count unknowns and equilibrium conditions again - there are now in the case of this system more conditions of equilibrium have to be satisfied than there are unknowns. For equilibrium, investment spending has to match savings: for entrepreneurial satisfaction, spending on investment goods must also correspond to the values placed upon them by entrepreneurs. It may well be that planned investment spending cannot meet both conditions at once: i.e. the system is over-determined. Equilibrium may not be attainable via price adjustment. The crux of the matter is not simply that prices should be free to express existing conditions of demand and supply: rather it is these conditions, specifically conditions of demand for output, not prices per se, that are "wrong".

The Morishima perspective (his emphasis on possible over-determination) is, we can say, relevant to any income-expenditure system, whether modelled in classical or Walrasiann terms. What matters for macro stability is whether demand for output automatically matches the value of what is produced, or being independently determined, can take a value which exceeds or falls short of that of the output available for purchase. Only in the case of a closed system, governed by Say's Law, is the aggregate demand function guaranteed to be "tame" and the correspondence of the value aggregate demand and of aggregate supply certain. If the conditions of production and the factors which determine planned aggregate demand are not compatible, in the absence (as in the Keynesian system) of any automatic adjustment mechanism, positive government intervention may be needed to change the parameters of the system, by directly creating demand and by altering the climate of business confidence and expectations.

\section{A summing up}

To recap briefly on the argument so far. Neoclassical theory (pre-Keynes) made much of the idea that the economy possesses a natural tendency to equilibrium with full employment and that the free working of the price mechanism could be expected to generate that state of affairs. Ceteris paribus, flexibility of real wages (free movement of the labour supply curve) would ensure full employment of labour, and the so-called "interest rate mechanism" would establish a "natural" rate of interest and which savings and intended investment would balance: all labour (allowing for temporary, frictional unemployment of people between jobs) would be employed and all output produced by that labour would be purchased either

for consumption or investment purposes. However, if wages were sticky, or the rate of interest failed to adjust as it should, the occurrence of unemployment could be expected. 
None of this Keynes accepted: his diagnosis attributes lack of employment to lack of demand for output, not excessive real wages; he rejected the notion of the interest rate equilibrating mechanism, finding the rate of interest to be of a different nature and to play a different role from that attributed to it in the conventional theory. For Keynes, aggregate demand for output, an independent and potentially troublesome variable was the important determinant of the level of activity: trouble in the form of unemployment was not due to inflexibility of wages or interest rates. When the suggestion was advanced that downward flexibility of the general price level might help boost aggregate demand in recession, he had no time for such a notion - more likely, he (and other authorities) thought that, with bankruptcies and expectations of further price decline, deflation would worsen rather than improve the situation. Finally, we emphasise that not only are these specific instances of price adjustment beside the point as regards the question of full employment, even if interest rates, real wages and the price level were to be as flexible as might be wished, such adjustments may not be enough. We have noted the contention that, in the case of a surplusproducing economy operating in a world of uncertainty, it is probable that the system is overdetermined, in which case it may be impossible, under existing circumstances, that all conditions of equilibrium can, at the same time, be satisfied. Price flexibility is therefore no longer the be-all and the end-all.

Thus we have arrived at a peculiarly Keynesian understanding - that the direct implication of bringing human decision-making into such a context is that an aggregate investment function must be regarded as an independent determining factor - "untamed" and unreliable: consequently, there is no room for Say's Law. The "natural" state of the system need not be one of full employment, rather it corresponds to the levels of output and employment as determined by aggregate demand - recognizing that, under real world conditions of uncertainty, aggregate demand is determined independently of, and may not be consistent with, aggregate supply.

\section{Current theoretical fashion}

But fashionable opinion, as propounded today in the standard macro texts, is dramatically different from that of the Keynesian era. The analytical model which presently dominates undergraduate macroeconomics teaching - the "ADAS" model. returns to the pre-Keynes focus on price flexibility as the means of maintaining full employment. This construction, widely employed in the textbook literature, puts the whole emphasis on price adjustment as the mechanism by which full employment equilibrium is ensured. Disequilibrium is attributed to wage and price inflexibility; recovery, it is alleged, is ensured by appropriate price adjustment. $^{11}$

\footnotetext{
${ }^{11}$ For fuller discussion of the incoherent nature and the inadequacies of the ADAS model see Grieve (1998, 2010), Moseley (2010) and Rao (1998).
} 
As readers will be aware, the ADAS model consists (diagrammatically) of two curves: (i) an AD ("aggregate demand") function which purports to show real aggregate demand as an inverse function of the price level and (ii) an AS ("aggregate supply") function; the later comes in two forms - as a vertical long-run AS curve which indicates that in the longer-term output is independent of the price level and a positively-sloped short-run AS curve which represents output as, in the short-run, varying positively with the price level.

On both the demand and supply sides of the model, everything depends on the degree of price flexibility. Changes in the volume of monetary expenditure affect output and employment only if money prices change in a greater proportion than money wages, so causing real wages to alter, and thus (according to this purely "classical" analysis) affecting employment and output. For employment to return to the "natural rate" money wages have to catch up with the change in prices. Likewise, on the AD side, the degree of price flexibility is critical: subsequent to some change in spending (represented by a shift of the $\mathrm{AD}$ curve, the real value of expenditure can be restored to compatibility with the volume of employment as determined in the (neoclassical) labour market by an appropriate degree of deflation (or inflation, as the case might be). Again we can say - from this theoretical perspective - all that is required to re-establish equilibrium at full employment is the appropriate adjustment of real wages (money wages relative to prices) and of the price level. Pas de probléme!

As regards the above ADAS story - two matters of concern, both involving the facile supposition that price changes guarantee correction of disequilibrium - are evident. We have here a reversion to the old pre-Keynesian model of the labour market, in which employment is determined by the level of real wages against the marginal product of labour schedule, so that unemployment is explained by excessive real wages due to an inappropriate position of the labour supply curve (wage demands are too high). The positively-sloped AD curve implies the complete neglect of all the reservations expressed in the past about the wealth effect on demand - price level adjustment is blindly presented as an effective means of changing (increasing) aggregate demand. This is a model which has no room either for an aggregate demand function which is independent of aggregate supply, or for any notion of involuntary unemployment. It is important also, when the ADAS model is under discussion, to be aware that that the construction is fundamentally incoherent. The model is unfit for purpose. $^{12}$

\footnotetext{
${ }^{12}$ It is worth noting that the AD/AS hotchpotch has been equally condemned from a purist New Classical perspective. Thus Barro and Grilli (1994, p.428):The main problem with the AS-AD framework is that the various pieces of the model are contradictory. The AD curve reflects the underlying IS/LM model . . . The AS curve assumes that producers (and workers) can sell their desired quantities at the going price P. That is why the quantity rises when $\mathrm{P}$ increases relative to $\mathrm{P}^{\mathrm{e}}$ (the expected price level). This set-up is inconsistent with the Keynesian idea - present in the IS/LM model and therefore in the AD curve - that producers and workers are constrained by aggregate demand in their ability to sell goods and services.
} 
Each curve, AD (which is derived from ISLM) and AS (which represents the pre-Keynesian, Say's Law theory of employment) in fact constitutes what David Collander describes as an "aggregate equilibrium curve", meaning that the two parts of the model, AD and AS, simultaneously describe different equilibrium levels of output as corresponding to the same price level. Not only therefore is the ADAS model made of component parts involving heavy and unpersuasive reliance on the efficacy of price adjustment (of real wages and of the price level) to correct disequilibrium states, the component elements represent rival, alternative macro theories, and are consequently incompatible.

\section{Conclusions}

It has been our purpose to question the common presumption that (downward) flexibility of wages and prices is enough to ensure - at least eventually - the attainment of full employment. Too little attention, we conclude, is paid to the possibility that, even with wage and price flexibility, such adjustments may be incapable of reconciling demand and supply throughout the economy so as to generate full employment. The problem may be of a more fundamental nature than one of mere stickiness of prices which prevents the ready attainment of an existing set of market clearing values. It may well be the case, in a world of uncertainty, with saving and investment, that, in given circumstances, no set of equilibrium prices actually exists to be reached through the free functioning of the price mechanism: the problem is not simply that prices fail to adjust, but that the state of aggregate demand is incompatible with the conditions of labour supply. What is required is a fundamental change in the state of those factors - namely current expenditure plans - which determine the level of activity within the economy. We suggest that the convention of taking it as "reasonable" to assume the existence of a set of equilibrium values ceases to be reasonable if the Walrasian general equilibrium approach is extended beyond its initial application to the case of shipwrecked mariners swapping goods on a desert island beach. Decision making in the real world is much more fraught and difficult: socially optimal outcomes cannot be guaranteed. Sticky wages or prices are not the relevant constraints on recovery; inflexibility in the downward direction of money wages and prices may actually, as Keynes suggested, be beneficial, contributing to stability rather than inhibiting adjustment to full employment equilibrium.

We note too it is unfortunate that so much macroeconomic discussion is today commonly conducted in terms of a theoretical model which cannot but confuse. The presently fashionable ADAS construction has rightly been condemned as a muddled hybrid which should have no place in macro analysis. The whole conception implies, in the macro context, an inappropriate analogy with market adjustment at the microeconomic level. Not only that, each of the incompatible individual parts of the model involves unjustifiable assumptions about the benign consequences of price effects - changes of real wages on employment, changes in the price level on aggregate demand. To explain changes in employment by 
reference to changes in real wages takes us back to the days of Professor Pigou: to presume that deflation will have a positive effect on aggregate demand is to overlook much theoretical discussion and empirical evidence which points to the contrary conclusion. The presumption that price flexibility ensures full employment turns the theoretical clock back eighty years.

\section{REFERENCES}

Barro, R. and V. Grilli, (1994), European Macroeconomics. Basingstoke: Macmillan.

Collander, D. C. (1995), "The Stories We Tell: A Reconsideration of AS-AD Analysis". Journal of Economic Perspectives, 9 (3), pp.169-88.

Dornbusch, R. and S. Fischer (1990), Macroeconomics (5 ${ }^{\text {th }}$ ed.). New York: McGraw-Hill.

Friedman, M. (1968), “The Role of Monetary Policy”. American Economic Review, 58 (1), pp.1-17.

Grieve, R. H. (1998), “Two Into One Won’t Go”. In B. B. Rao (ed.), Aggregate Demand and Supply: A Critique of Orthodox Macroeconomic Modelling. London: Macmillan.

Grieve, R. H.(2001), “No Fabrication Involved”. Journal of Economic Studies, 28 (2), pp.141-48.

Grieve, R. H. (2010), Review of Radical Political Economics, 42 (3), pp.315-20.

Hahn, F. (1982), "Reflections on the Invisible Hand". Lloyds Bank Review, 144 (April), pp.1-21.

Johnson, H. G. (1971), Macroeconomics and Monetary Theory. London: Gray-Mills.

Keynes, J. M. (1936), The General Theory of Employment, Interest and Money. London: Macmillan.

Keynes, J. M. (1937), "The General Theory of Employment". Quarterly Journal of Economics; reprinted in R. W. Clower (ed.) (1973), Readings in Monetary Theory. Harmondsworth: Penguin; reprinted also in Collected Writings, Vol. XIV, pp.109-23. London: Macmillan.

Keynes, J. M. (1939), “Relative Movements of Real Wages and Output”. Economic Journal, 49, pp.34-51.

Keynes, J. M. (1973), Collected Writings, Vol. XIV. London: Macmillan.Laidler, D. (1999), Fabricating the Keynesian Revolution. Cambridge: Cambridge University Press. Leijonhufvud, A. (1968), On Keynesian Economics and the Economics of Keynes. New York: Oxford University Press.

Mankiw, N. G. (1994), Macroeconomics (2 ${ }^{\text {nd }}$ ed.). New York: Worth. 
Morishima, M. (1977), Walras's Economics. Cambridge: Cambridge University Press.

Moseley, F (2010), Review of Radical Political Economics, 42 (3), pp.308-14.

Patinkin, D. (1959), "Keynesian Economics Rehabilitated: A Rejoinder to Professor Hicks". Economic Journal, LXIX, pp.582-7.

Patinkin, D. (1965), Money, Interest and Prices (2 ${ }^{\text {nd }}$ ed.). New York: Harper \& Row.

Phelps, E. S. (1967), "Phillips Curves, Expectations of Inflation, and Optimal Unemployment over Time”. Economica, 34 (3), pp.254-81.

Pigou, A. C. (1933), The Theory of Unemployment. London: Frank Cass.

Rao, B. B. (ed.) (1998), Aggregate Demand and Supply: A Critique of Orthodox Macroeconomic Modelling. London: Macmillan.

Sraffa, P. (1960), The Production of Commodities by Means of Commodities: Prelude to a Critique of Economic Theory. Cambridge: Cambridge University Press.

Weintraub. E. R. (1974), General Equilibrium Theory. London: Macmillan. 
